\title{
BPA - an endocrine disrupting compound in water used for drinking purposes, a snapshot from South Poland
}

\author{
Ewa Kmiecik ${ }^{1}$, Katarzyna Styszko², Katarzyna Wątor ${ }^{3}$, Małgorzata Dwornik ${ }^{4}$, \\ Barbara Tomaszewska ${ }^{5}$
}

${ }^{1}$ AGH University of Science and Technology; al. A. Mickiewicza 30, 30-059 Krakow, Poland; e-mail: ewa.kmiecik@agh.edu.pl; ORCID ID:0000-0003-3249-4642

${ }^{2}$ AGH University of Science and Technology; al. A. Mickiewicza 30, 30-059 Krakow, Poland; e-mail: styszko@agh.edu.pl; ORCID ID: 0000-0003-0092-3772 (corresponding author)

${ }^{3}$ AGH University of Science and Technology; al. A. Mickiewicza 30, 30-059 Krakow, Poland; e-mail: katarzyna.wator@agh.edu.pl; ORCID ID: 0000-0002-1921-5146

${ }^{4}$ e-mail: malgorzata.dwornik@interia.pl

${ }^{5}$ AGH University of Science and Technology; Mineral and Energy Economy Research Institute, Polish Academy of Sciences; ul. J. Wybickiego 7A, 31-261 Krakow, Poland; e-mail: bts@agh.edu.pl; ORCID ID: 0000-0002-4780-1580

(C) 2020 Authors. This is an open access publication, which can be used, distributed and reproduced in any medium according to the Creative Commons CC-BY 4.0 License requiring that the original work has been properly cited.

Received: 19 December 2019; accepted: 10 February 2020; first published online: 20 February 2020

\begin{abstract}
Bisphenol A (BPA) is a chemical produced in large quantities for use primarily in the production of polycarbonate plastics and epoxy resins. As an endocrine disrupting compound, it has been included in the list of substances requiring special supervision as a very high-risk substance due to its toxic influence on reproduction. BPA with a reference value of $0.01 \mu \mathrm{g} / \mathrm{L}$ was included in the Drinking Water Directive revision (DWD 2018). This paper presents the results of preliminary studies aimed at identifying the occurrence of BPA in different types of water, i.a. groundwater captured with house wells or flowing wells in a selected location in southern Poland. These waters are commonly used as a source of water intended for human consumption and their quality is not regularly controlled. Additional tests were carried out for surface water, as well as water from springs used for drinking purposes. The authors also analysed tap water from various sources, i.e. surface and groundwater, as the final product of the drinking water production cycle.

The results indicate the presence of BPA in water and the necessity of a detailed study on the risk of the BPA occurring in groundwater, especially in domestic wells.
\end{abstract}

Keywords: emerging contaminants, endocrine disrupting compounds, groundwater protection, groundwater domestic wells, bisphenol A

\section{INTRODUCTION}

The increasing use of pharmaceuticals, both for humans and animals, also results in a growth in the concentration of endocrine disrupting compounds and products of their metabolism in sewage, and thus in surface water, groundwater (i.a. domestic wells) and tap water, which are subsequently consumed by humans (Loos 2012, 2015). The seriousness of the problem is documented by the rich literature devoted to emerging contaminants (EC) and endocrine disrupting compounds (EDCs) in the aquatic environment, e.g.: Cunningham et al. (2006), Kümmerer (2009), Loos et al. (2010), 
Snyder \& Benotti (2010), Sanderson (2011), Kozisek et al. (2013), Rocha et al. (2013), Webb et al. (2013), Küster \& Adler (2014), Schaider et al. (2014), Corrales et al. (2015), Lin et al. (2015), Baranauskaite-Fedorova et al. (2016), Clayton (2016), Paxéus et al. (2016), Yan et al. (2016), Bilal et al. (2018), Rasheed et al. (2019), Wazir \& Mokbel (2019).

According WHO (2012) an endocrine disruptor "is an exogenous substance or mixture that alters function(s) of the endocrine system and consequently causes adverse health effects in an intact organism, or its progeny, or (sub)populations" and a potential endocrine disruptor "is an exogenous substance or mixture that possesses properties that might be expressed to lead to endocrine disruption in an intact organism, or its progeny, or (sub)populations".

EDCs enter into the environment and groundwater through many routes: human or animal excreta, wastewater effluent, treated sewage sludge, industrial waste (also pharmaceutical), medical waste from health-care and veterinary facilities, landfill leachate, surface runoff biosolids, as well as indirectly through the process of groundwater-surface water exchange (Lapworth et al. 2012, WHO 2012). Groundwater, especially that from shallow aquifers, is intensively supplied by the infiltration of atmospheric precipitation. Precipitation transports different pollutants by washing dumping grounds, urban-industrial agglomerations, areas of crops, etc. Migration of these substances is a major threat to groundwater resources (Witczak et. al. 2013). The domestic wells capturing shallow groundwater are most liable to pollution. EDCs and their metabolites undergo natural attenuation by adsorption, dilution or degradation in the environment, depending on their hydrophobicity, biodegradability and the temperature. Therefore, these compounds in water sources and drinking water are often present in trace concentrations, as they would have undergone metabolism and removal through natural processes and, if applicable, wastewater and drinking water treatment processes (WHO 2012).

The Water Framework Directive (WFD 2000) established a strategy for the prevention of water pollution covering i.a. identification of priority substances among those which represent a significant risk to the aquatic environment or through it at the European Union level. In 2013, the European Commission introduced the obligation to draw up the so-called watch lists, covering such substances (EU 2013). Watch lists (EU 2015) concern only surface waters. The Groundwater Directive (GWD 2006) aims to prevent and combat groundwater pollution in the EU. In a document "Developing a groundwater watch list for substances of emerging concern: a European perspective" almost 280 compounds are considered as hazardous for humans, however, in most European countries only 31 of them were examined (Lapworth et al. 2019). Bisphenol A (with a limit reference value of $0.01 \mu \mathrm{g} / \mathrm{L}$ ) was included in Part B of Annex 1 of the Drinking Water Directive revision (DWD 2018). This regulation will also be applied for groundwater, including domestic wells often used as a source of drinking water without regular quality control and treatment. The paper presents the results of preliminary studies aimed at identifying bisphenol $\mathrm{A}$ - an endocrine disrupting compound - in some sites in southern Poland.

Bisphenol A (BPA) is a chemical produced in large quantities for use primarily in the production of polycarbonate plastics and epoxy resins. It is mainly used in combination with other chemicals to manufacture plastics and resins (Pubchem 2017). It has been included in the list of substances requiring special supervision as a very high-risk substance due to its toxic influence on reproduction (ED/01/2017, ED/01/2018). Its endocrine disrupting activity is associated with cardiovascular disease, diabetes, obesity, and liver dysfunction (EU 2010).

BPA has been proven to have estrogenic activity even at concentrations below $1 \mathrm{ng} / \mathrm{L}$ (Rykowska \& Wasiak 2006). The effects of exposure to BPA can be particularly harmful to i.a. infants and young children because of a lack of feedback regulating the activity, synthesis, and elimination of hormones (Rykowska \& Wasiak 2006, Careghini et al. 2015).

Endocrine disrupting compounds are more widely determined in water bodies. However, it turns out that EDCs, like alkylphenols and bisphenol A, are emitted into the atmosphere during fuel combustion, mainly because of technical reasons (since many domestic stoves are defective) and economic ones (since in many cases waste combustion is much cheaper than burning ecological fuel) 
(Alliot et al. 2014, Lyons et al. 2014, Vorkamp et al. 2014, Salgueiro-González et al. 2015). Many studies have been conducted on BPA in soil and aquatic environments as well as the widespread and continuous human exposure to bisphenol through food, drinking water, dental sealants, cell phones and inhalation of indoor dust (Wilson et al. 2001, Rudel et al. 2003, Vandenberg et al. 2007, Fu \& Kawamura 2010). Bisphenol A is not likely to occur in the gas phase of the atmosphere as its vapor pressure is very low. But as atmospheric releases of bisphenol are reported during production, an association with aerosols particulates is possible. Bisphenol has attracted considerable public attention due to its potential association with adverse health effects such as prostate cancer, obesity, neurobehavioral and reproductive problems (Krishnan et al. 1993, Vogel 2009, Fu \& Kawamura 2010). BPA was detected in $40 \%$ of groundwater bodies identified as drinking water sources investigated in Europe (Loos et al. 2010, Arnold et al. 2013, Postigo \& Barceló 2015).

The achievements of Polish researchers on the scope of this form of pollution as an emerging group of contaminants are significant. Literature studies of the occurrence of the pharmaceuticals, EDCs and their residues in Poland have focused mainly on sewage, surface water, and water intended for human consumption. However, there is little information about groundwater pollution caused by these substances. A comprehensive study on the occurrence, removal, mass loading, and environmental risk assessment of 19 multiclass emerging organic contaminants (i.a. bisphenol A) in groundwater from two MSW landfill sites located in northeast Poland is presented in Kapelewska et al. (2018). BPA was found in all of the analyzed samples. Its concentrations in groundwater were at the level of $<0.003-6.88 \mu \mathrm{g} / \mathrm{L}$. In 2016 Polish Geological Institute-National Research Institute (PGI-NRI) conducted pilot studies on the amounts of the pharmaceuticals in groundwater in Poland (Kuczyńska 2017). Among the analyzed parameters were compounds belonging to the group of endocrine disruptors, i.e. estrone, estriol, 17-alpha-ethinylestradiol, 17-beta-estradiol, but they were found only in selected areas. BPA was not analyzed during this research study. Preliminary results of the pharmaceutical residues in the groundwater of southern Poland were presented by the authors of the work at several worldwide conferences (Kmiecik et al. 2017a, 2017b, 2018, Wątor et al. 2017).

In this paper, the results of simple tests are presented. The aim of the research was the determination of the occurrence of BPAs in different kinds of water which are used for drinking purposes. Also, samples of total amounts of BPAs suspended in air particles and soils were tested to indicate possible routes of BPA migration in the environment.

\section{MATERIALS AND METHODS}

During the first sampling campaign (in February 2017) grab water samples were collected. The location of sampling points is presented in Figure 1.

Samples of water intended for human consumption were collected from taps from different sources (surface water, groundwater and domestic wells in the vicinity of agricultural areas) (Tab. 1 on the interleaf). The samples of flowing surface water (rivers) and groundwater (wells and spring) were also taken from areas where they are used for drinking purposes.

Water samples were collected in accordance with the procedures given in the 5667 series ISO standards (Water quality - Sampling) and transferred into $500 \mathrm{~mL}$ glass bottles. Samples were stored in a fridge and transported to the laboratory in a short time (a few hours).

Solid phase extraction (SPE) was used for the extraction of the BPA from the aqueous samples. SPE was carried out with a System BAKER spe 12G. Oasis HLB extraction cartridges were conditioned with $\mathrm{CH}_{3} \mathrm{OH}(2 \mathrm{~mL})$ and $\mathrm{H}_{2} \mathrm{O}(2 \mathrm{~mL})$. Samples (1 L) were spiked with $200 \mathrm{ng}$ of internal standard (bisphenolA-D16) and then passed through the HLB cartridge at a rate of $6 \mathrm{~mL} / \mathrm{min}$. After the extraction was completed, the cartridges were dried under full vacuum for $20 \mathrm{~min}$. The elution was performed using $4 \mathrm{~mL}$ of $\mathrm{CH}_{3} \mathrm{OH}$. The extracts were dried to dryness under argon at $35^{\circ} \mathrm{C}$ and then dissolved in $200 \mu \mathrm{L}$ of derivatization reagent. The sialylation process with BSTFA $+1 \%$ TMCS was carried out at $65^{\circ} \mathrm{C}$ for $35 \mathrm{~min}$ in a thermo-block. Solutions were then analyzed by GC-MS/MS (Nosek et al. 2014). 

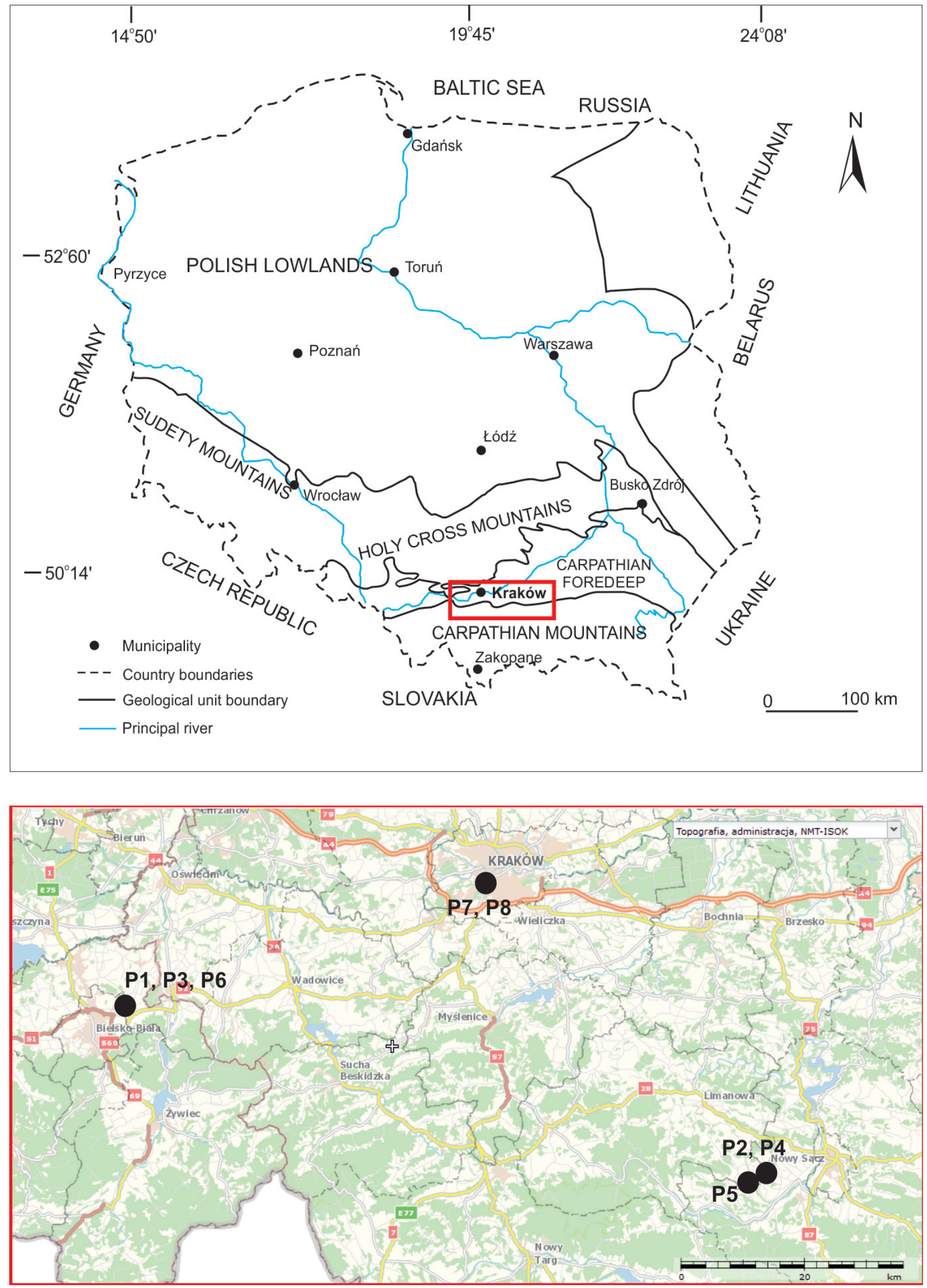

Fig. 1. Location of sampling points P1-P8 
Table 1

Characteristic of sampling sites and summary of sampling series

\begin{tabular}{|c|c|c|c|c|c|}
\hline \multirow{2}{*}{$\begin{array}{l}\text { Sampling } \\
\text { point Id }\end{array}$} & \multirow{2}{*}{$\begin{array}{l}\text { Kind } \\
\text { of water }\end{array}$} & \multirow{2}{*}{ Characteristics } & \multicolumn{3}{|c|}{ Sampling series } \\
\hline & & & $1^{\text {st }}$ (II 2017) & $2^{\text {nd }}($ XI 2017) & $3^{\text {rd }}$ (II 2018) \\
\hline P1 & \multirow{2}{*}{$\begin{array}{l}\text { surface } \\
\text { water }\end{array}$} & $\begin{array}{l}\text { The stream flows parallel to the road, between } \\
\text { houses and farms where not all farms are connected } \\
\text { to the sewage system (cesspool), farmlands and } \\
\text { numerous forest areas are found around the farms }\end{array}$ & \multirow{8}{*}{$\begin{array}{l}\text { water (glass } \\
\text { containers) }\end{array}$} & - & - \\
\hline $\mathrm{P} 2$ & & $\begin{array}{l}\text { It flows between the houses and farms through the } \\
\text { areas where not all of the farms are connected to the } \\
\text { sewage system (cesspool) and near to the farmlands }\end{array}$ & & $\begin{array}{l}\text { water } \\
\text { (plastic } \\
\text { container) }\end{array}$ & $\begin{array}{l}\text { water } \\
\text { (plastic } \\
\text { and glass } \\
\text { container) }\end{array}$ \\
\hline P3 & $\begin{array}{l}\text { spring/ } \\
\text { ground- } \\
\text { water }\end{array}$ & $\begin{array}{l}\text { The spring flows from the slope of the mountain, } \\
\text { the intake is enclosed by stone slabs, water flows } \\
\text { in a continuous stream along a rocky grove, forest } \\
\text { areas are mostly found around as well as farmlands, } \\
\text { farms and house where not all farms are connected } \\
\text { to the sewage system (cesspool). The water is } \\
\text { a source of drinking water for residents }\end{array}$ & & $\begin{array}{l}\text { water } \\
\text { (plastic } \\
\text { container) } \\
\text { soil }\end{array}$ & $x_{1}$ \\
\hline $\mathrm{P} 4$ & \multirow{2}{*}{$\begin{array}{l}\text { ground- } \\
\text { water }\end{array}$} & $\begin{array}{l}\text { Domestic well, connection at home, galvanized steel } \\
\text { pipes, } 30 \text {-year-old installation, the well is located } \\
\text { about } 50 \mathrm{~km} \text { from the bank of river P2 }\end{array}$ & & $\begin{array}{l}\text { water } \\
\text { (plastic } \\
\text { container) } \\
\text { soil air }\end{array}$ & $\begin{array}{l}\text { water } \\
\text { (plastic } \\
\text { container) }\end{array}$ \\
\hline P5 & & $\begin{array}{l}\text { Domestic well, the connection at home, galvanized } \\
\text { steel pipes, } 30 \text {-year-old installation }\end{array}$ & & $\begin{array}{l}\text { water } \\
\text { (plastic } \\
\text { container) }\end{array}$ & - \\
\hline P6 & \multirow{3}{*}{ tap water } & $\begin{array}{l}\text { Treated surface water, central installation which is } \\
\text { about } 60 \text {-year-old, } 5 \text {-year-old installation at home, } \\
\text { plastic and steel }\end{array}$ & & - & - \\
\hline P7 & & $\begin{array}{l}\text { Treated surface water, central installation is about } \\
15 \text {-year-old, } 15 \text {-year-old installation at home, plastic } \\
\text { and steel }\end{array}$ & & - & - \\
\hline P8 & & $\begin{array}{l}\text { Groundwater intake, central installation which is } \\
\text { about } 20 \text {-year-old, 1-year-old installation at home, } \\
\text { steel }\end{array}$ & & - & - \\
\hline
\end{tabular}

The analysis was carried out with the usage of Thermo Scientific GC Trace 1300 gas chromatography coupled to a ITQ 900 ion trap mass spectrometer and a TriPlus RSH autosampler. The flow of helium through a GC column was constant and set at $1 \mathrm{~mL} / \mathrm{min}$. The programmable temperature of the vaporization injector was maintained at $250^{\circ} \mathrm{C}$, the transfer line at $250^{\circ} \mathrm{C}$ and the ion source at $250^{\circ} \mathrm{C}$. The injector was operated at splitless conditions for $2 \mathrm{~min}$. The volume of injections was $1 \mu \mathrm{L}$. All the compound separations were performed on a TG-SQC capillary column from Thermo Scientific that had a $30 \mathrm{~m} \times 0.25 \mathrm{~mm}$ inner diameter and a film thickness of $0.25 \mu \mathrm{m}$ (5\% phenyl $95 \%$ dimethylpolysiloxane). The temperature program was as follows: $70^{\circ} \mathrm{C}$ for $2 \mathrm{~min}$, from 70 to $320^{\circ} \mathrm{C}$ at $20^{\circ} \mathrm{C} \mathrm{min}^{-1}$, and finally $5 \mathrm{~min}$ at $320^{\circ} \mathrm{C}$. The analyses were performed in a positive mode, an electron energy $70 \mathrm{eV}$ and emission current $250 \mu \mathrm{A}$. Helium (99.999\%) was used as a collision gas with a flow of $0.3 \mathrm{~mL} / \mathrm{min}$. Mass spectrometry analyses were performed in the multiple reaction monitoring (MRM) mode measuring the fragmentation of the precursor ions. Data was collected, analyzed and processed using a Thermo Xcalibur. Limits of detection and quantification were calculated based on signal to noise ratios $(\mathrm{S} / \mathrm{N})$ of 3 and 10 , respectively (Tab. 2). Deuterated internal standard (bisphenol A-D16) was added before SPE extraction to compensate for losses or enhancement of compounds during both the sample preparation procedure and resulting from matrix effects. The correlation coefficient $\left(r^{2}\right)$ of the calibration curve was 0.9987 for the concentration range studied $(0-500 \mathrm{ng} / \mathrm{mL})$. 
Table 2

GC-MS/MS method parameters for the analysis of BPA (calculated during method validation)

\begin{tabular}{|c|c|c|c|}
\hline Retention time $[\mathrm{min}]$ & $\begin{array}{c}\mathbf{m} / \mathbf{z} \text { for characteristic ions } \\
\text { (for quantification) }\end{array}$ & $\begin{array}{c}\text { Method detection limit } \\
\text { MDL [ng/L] }\end{array}$ & $\begin{array}{c}\text { Method quantification } \\
\text { limit MQL [ng/L] }\end{array}$ \\
\hline 13.37 & $357 \rightarrow 191,267$ & 0.15 & 0.5 \\
\hline
\end{tabular}

The recovery of BPA was $88 \%$. The estimated measurement uncertainty is $30 \%$ (Kmiecik et al. 2018). During the second series (November 2017) water samples from selected points were collected where the highest BPA concentrations were observed in the first series (P2-P5).

In parallel, soil samples from the investigated areas were also taken (points P3, P4). Topsoil samples from the depth $0-20 \mathrm{~cm}$ (about 10 primary samples) were placed in a container from randomly selected points around the well/spring using an Egner's stick. All primary samples were mixed and averaged, and a bulk sample of approximately $0.5 \mathrm{~kg}$ was separated. Such collected samples were immediately delivered to the laboratory in a string bag. Soil samples were frozen and dried by lyophilisation, sieved through a $2 \mathrm{~mm}$ sieve and stored at $4^{\circ} \mathrm{C}$ until analysis. Dried soil samples of $5 \mathrm{~g}$ were spiked with 100 ng of BPA D16 and extracted with $10 \mathrm{~mL}$ of methanol for $1 \mathrm{~h}$ using horizontal shaker at $50 \mathrm{rpm}$, and centrifuged. The final extracts were evaporated to dryness and reconstituted in $100 \mu \mathrm{L}$ of BSTFA+1\% TMCS and derivatized at $65^{\circ} \mathrm{C}$ for $35 \mathrm{~min}$. The recovery of BPA was $61 \%$. The estimated measurement uncertainty is $19 \%$.

From point (P4), an additional sample of the total suspended in the air particles (TSP) was collected. A low volume sampler was equipped with a filter holder, needle valve, membrane pumps and gas meters. The sampler worked with an air flow of $1.4 \mathrm{~m}^{3} / \mathrm{h}$. Samples were collected on quartz fibre filters (Pallflex, Pall Life Sciences) with a $47 \mathrm{~mm}$ diameter. Before sampling, the filters were thermally pre-cleaned at $550^{\circ} \mathrm{C}$ for $5 \mathrm{~h}$, cooled and equilibrated to constant humidity. Two samples of TSP were collected, in $70 \mathrm{~h}$. The sampled filters were equilibrated for $24 \mathrm{~h}$ to achieve conditions comparable with the conditions of the weighing of empty filters. The mass of the particulate matter was obtained as an average of the three subsequent weighing results of each filter. The OHAUS Discovery DV215CD balance with an accuracy of $\pm 0.01 \mathrm{mg}$ was used for weighing. The circular filter aliquots with a diameter of $22 \mathrm{~mm}$ were cut from the filters and then spiked with $10 \mu \mathrm{L}(10 \mathrm{ng} / \mu \mathrm{L})$ BPA D16 solution, after that extracted twice with $3 \mathrm{~mL}$ dichloromethane and $2 \mathrm{~mL}$ cyclohexane, for $40 \mathrm{~min}$. The volume of combined extracts was reduced to $250 \mu \mathrm{L}$, using a gentle stream of argon at $35^{\circ} \mathrm{C}$. The $100 \mu \mathrm{L}$ of concentrate was finally transferred into the chromatographic vial, derivatized with BSTFA+1\% TMCS $\left(65^{\circ} \mathrm{C}, 35 \mathrm{~min}\right)$ and analyzed with GC-MS/MS. The recovery of BPA was $67 \%$.

During the third series of samples collection (February 2018), water samples from points P2 and $\mathrm{P} 4$ were collected. In the case of P2, they were placed in plastic ( $\mathrm{p}$ - BPA free) and glass (g) containers.

\section{RESULTS AND DISCUSSION}

Bisphenol A was found in all samples tested during the $1^{\text {st }}$ series (Fig. 2). Their concentrations range from $6 \mathrm{ng} / \mathrm{L}$ (P7) through 351-427 ng/L in surface water (P1, P2) to $629 \mathrm{ng} / \mathrm{L}$ in spring water (P3). The lower concentration of bisphenol A in the tap water (P6-P8 - 6-53 ng/L) confirms their removal during the water treatment process. The highest concentrations of bisphenol A were found in the sample of spring water $(\mathrm{P} 3-629 \mathrm{ng} / \mathrm{L})$ and groundwater from domestic wells (P4 - $518 \mathrm{ng} / \mathrm{L}$, P5 - $255 \mathrm{ng} / \mathrm{L}$ ) located in villages where the sewage system is not very common and surface runoff is possible. BPA concentrations in all samples except P7 exceed the maximum permissible limit sets in the drinking water directive (DWD 2018).

Bisphenol A was one of the most relevant compounds detected in European groundwater described in the study of Loos et al. (2010) (autumn sampling series, the maximum measured concentration of BPA $2.3 \mu \mathrm{g} / \mathrm{L}$ ). In groundwater, higher BPA concentration levels were also observed than in surface water. Environmentally significant concentrations of EDCs are being detected in 
groundwater globally (Lapworth et al. 2012) but concentrations of these compounds change over time. The data from the literature indicate that the highest concentrations are observed in winter (Daneshvar et al. 2010, Baker \& Kasprzyk-Hordern 2013, Boleda et al. 2013, Paxéus et al. 2016, Petrie et al. 2016). The results of the first series concern only the instantaneous concentrations of bisphenol A in single water samples collected in February and therefore may be higher than in other seasons. It may be related to rainfall, temperature, etc. What is more, this series of samples was collected during the height of the heating season, after several months of the intensive combustion of various fuels in domestic boiler rooms, which may affect the results obtained for the determination of bisphenol A. Therefore, at the beginning of the heating season in November 2017, a second series of tests was carried out. Samples were collected in plastic containers (BPA free) from those points in which high concentrations of bisphenol A had been found in February (P2-P5). In parallel, soil samples were also taken (points P3, P4) and from point (P4) an additional sample of the total suspended in the air particles was collected. The results for water samples are also presented in Figure 2. This time, BPA concentrations in the surface water sample (P2) and groundwater samples (P3-P5) were at a very low level, about $1 \mathrm{ng} / \mathrm{L}$.

In the soil samples, BPA was determined at the level of $4 \mathrm{ng} / \mathrm{g}$ (P4) and $10 \mathrm{ng} / \mathrm{g}$ (P3). In the literature, there is only a little information about BPA in soil samples. For example, researchers have proven that the contamination of industrial soil with BPA was higher (mean concentration $11.28 \mathrm{ng} / \mathrm{g}$ ) than for agricultural soil (mean concentration $2.42 \mathrm{ng} / \mathrm{g}$ ) (Sánchez-Brunete et al. 2009, Fischer et al. 2014). BPA concentrations for landfill soil ranged from $<0.1$ to $2.8 \mathrm{ng} / \mathrm{g}$ (Hansen \& Lassen 2008, Sánchez-Brunete et al. 2009, Fischer et al. 2014). The results of the analysis performed for soil samples at points $\mathrm{P} 3$ and $\mathrm{P} 4$ are relatively high. Research provided by Styszko (2016) indicated that bisphenol A had relatively poor sorption properties which were dependent on the type of sediments/soils.

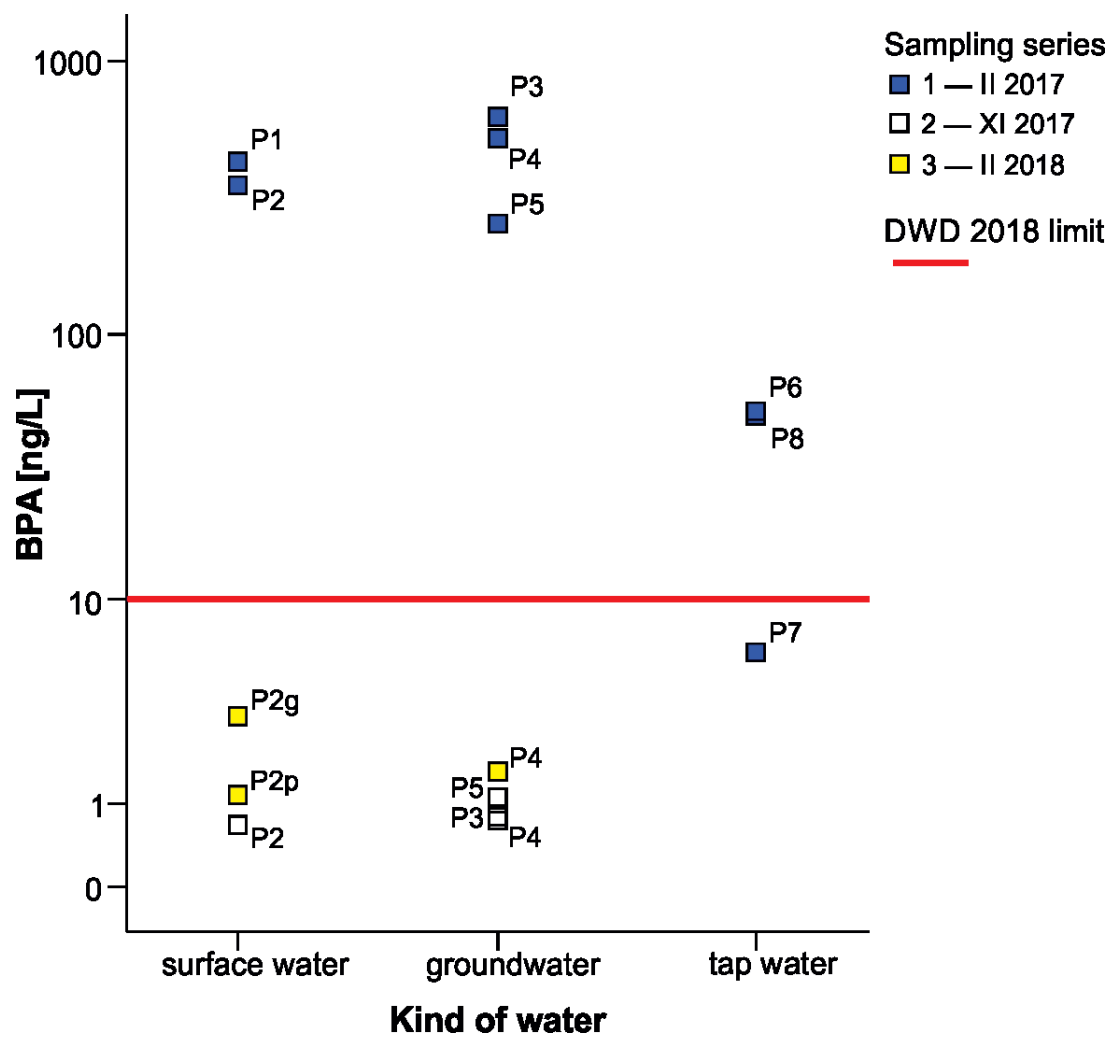

Fig. 2. The results of bisphenol A determination in the analyzed samples 
In the sample of air particulate matter from point P4, $2.83 \mathrm{ng} / \mathrm{m}^{3}$ of BPA was determined. Fu \& Kawamura (2010) showed that in the agricultural areas of China, BPA concentration in the air does not exceed $0.240 \mathrm{ng} / \mathrm{m}^{3}$, while in urban areas it reaches concentrations ranging from 0.020 to $2.340 \mathrm{ng} / \mathrm{m}^{3}$ (Kryłów \& Rezka 2017). A positive correlation was found in urban regions between BPA and 1,3,5-triphenylbenzene, a tracer for the burning of plastic, indicating that the open burning of plastics in domestic waste should be a significant emission source of atmospheric BPA (Fu \& Kawamura 2010). The concentration of BPA in the air particulate matter from point $\mathrm{P} 4$ suggests that one of the possible sources of this compound in the investigated areas, where neither industry nor high traffic occurs, is the burning of plastics in domestic waste. From the air, BPA can migrate to the soils and water surface and groundwater.

During the third series of sampling (February 2018) samples from points $\mathrm{P} 2$ and $\mathrm{P} 4$ were collected. In the case of $\mathrm{P} 2$, these were placed in plastic ( $\mathrm{p}$ - BPA free) and glass (g) containers. BPA was identified in all samples, also in small concentrations (Fig. 2), but higher than in the second series. In sample P4, BPA was measured at the level $1.61 \pm 0.37 \mathrm{ng} / \mathrm{L}$. There was a difference in BPA determination in sample P2 from the plastic $(1.13 \pm 0.17 \mathrm{ng} / \mathrm{L})$ and glass containers (3.17 $\pm 0.92 \mathrm{ng} / \mathrm{L}$ ), probably occurring during the sorption processes. The research will be expanded to explain the behavior of BPA under different conditions. Column and batch experiments are planned (Okońska \& Pietrewicz 2018, Okońska et al. 2019a, 2019b, 2019c).

In 2015, the European Food Safety Authority reduced the tolerable daily intake (TDI) for BPA from 50 to $4 \mu \mathrm{g} / \mathrm{kg}$ BW/day. TDI is "the maximum amount of a substance to which any individual can be exposed every day of his/her life, through all possible sources, without any risk to his/her health" (EFSA 2019). Maximum Allowable Dose Level (MADL) is the exposure level at which a chemical would have no observable reproductive effect even if a person were exposed to 1000 times that level. Goodman et al. (2017) estimated this parameter at the level of $157 \mu \mathrm{g} /$ day. Drinking water equivalent level (DWEL, ug/L) can be calculated from TDI, multiplying by the default adult body weight (about $70 \mathrm{~kg}$ ) and divided by average daily water consumption $(2 \mathrm{~L})$ :

$$
\begin{aligned}
\mathrm{DWEL} & =4 \mu \mathrm{g} / \mathrm{kg} \text { BW } / \text { day } \times 70 \mathrm{~kg} \mathrm{BW} / 2 \mathrm{~L}= \\
& =140 \mu \mathrm{g} / \mathrm{L} .
\end{aligned}
$$

In the Health Based Guidance for Water Health Risk Assessment Unit (MDH 2015) there are other BPA limits:

- Short-term Non-Cancer Health Risk Limit $($ nHRLShort-term $)=100 \mu \mathrm{g} / \mathrm{L}$,

- Subchronic Non-Cancer Health Risk Limit $($ nHRLSubchronic) $=20 \mu \mathrm{g} / \mathrm{L}$,

- Chronic Non-Cancer Health Risk Limit $($ nHRLChronic $)=$ nHRLSubchronic $=20 \mu \mathrm{g} / \mathrm{L}$.

The concentrations of BPA observed in the analyzed samples are lower than the above limits, therefore they do not pose a threat to the health of the people drinking this water.

\section{CONCLUSIONS}

Pollution of the environment by means of endocrine disrupting substances is an emerging problem. There is a lack of knowledge about the presence of many of them in the environment (i.a. in groundwater) and about the levels that could be harmful for human health. The main goal of the presented preliminary research was to identify the risk from exposure to BPA - an important endocrine disrupting compound - through consumption of drinking water from different sources, including groundwater from house (private) wells. These wells take water from Quaternary formations, so they are most exposed to contamination, also by EDCs. The problem is that the quality of groundwater taken from small domestic wells is not controlled and, even if it is, EDCs are not determined.

As the results of the conducted research show, BPA occurs in shallow groundwater in Poland, including water captured by small domestic wells. There is a need for regular research on the scope of the presence of BPA in groundwater. Meanwhile, the lack of analytical procedures constitutes a limitation to the reliable quantification of EDCs in groundwater, especially those occurring in very low concentrations, and affects the estimation of 
human exposure to the discussed pollutants. Although studies and reviews can be found in the literature on sources, occurrence, environmental behavior, and the fate of BPA, the pathway of this pollutant from sources to receptors should be subject to advanced research. This is because the information is still insufficient, mainly due to the complexity of the environmental systems which may determine an unexpected behavior of the BPA in the air, water, or soil. The consequences of BPA in aquatic ecosystems are of particular concern since living organisms are subjected to exposure, with potential consequences for future generations.

The research presented in this paper is ongoing. Samples are being collected with different frequencies, allowing us to determine the trends/ fluctuations of bisphenol in groundwater used for human consumption. The presented preliminary results indicated that there are changes in BPA concentrations during the course of a year. The influence of weather conditions such as precipitation, wind or temperature should be taken into account during the interpretation of results. The use of passive sampling or collection of composite samples (daily/week), column and batch experiments can give more reliable results which will help to identify the migration routes of bisphenol A into the tested groundwater.

\section{REFERENCES}

Alliot F., Moreau-Guigon E., Bourges C., Desportes A., Teil M.-J., Blanchard M. \& Chevreuil M., 2014. A multi-residue method for characterization of endocrine disruptors in gaseous and particulate phases of ambient air. Atmospheric Environment, 92, 1-8, https://doi. org/10.1016/j.atmosenv.2014.02.044.

Arnold S.M., Clark K.E., Staples C.A., Klecka G.M., Dimond S.S., Caspers N. \& Hentges S.G., 2013. Relevance of drinking water as a source of human exposure to bisphenol A. Journal of Exposure Science and Environmental Epidemiology, 23, 137-144, https://doi.org/10.1038/ jes.2012.6.

Baker D.R. \& Kasprzyk-Hordern B., 2013. Spatial and temporal occurrence of pharmaceuticals and illicit drugs in the aqueous environment and during wastewater treatment: New developments. Science of the Total Environment, 454-455, 442-456, https://doi.org/10.1016/j.scitotenv.2013.03.043.

Baranauskaitè-Fedorova I., Dvarionienė J. \& Nikiforov V.A., 2016. Management of pharmaceutical substances in the environment: Lithuanian case study. Water Science and
Technology, 74, 6, 1255-1265, https://doi.org/10.2166/wst. 2016.289.

Bilal M., Rasheed T., Iqbal H.M. \& Yan Y., 2018. Peroxidases-assisted removal of environmentally-related hazardous pollutants with reference to the reaction mechanisms of industrial dyes. Science of the Total Environment, 644, 1-13, https://doi.org/10.1016/j.scitotenv. 2018.06.274.

Boleda M.R., Galceran M.T. \& Ventura F., 2013. Validation and uncertainty estimation of a multiresidue method for pharmaceuticals in surface and treated waters by liquid chromatography-tandem mass spectrometry. Journal of Chromatography A, 1286, 146-158, https://doi. org/10.1016/j.chroma.2013.02.077.

Careghini A., Mastorgio A.F., Saponaro S. \& Sezenna E., 2015. Bisphenol A, nonylphenols, benzophenones, and benzotriazoles in soils, groundwater, surface water, sediments, and food: a review. Environmental Science and Pollution Research, 22, 5711-5741, https://doi. org/10.1007/s11356-014-3974-5.

Clayton H., 2016. EU strategic approach to pharmaceuticals in the environment (PIE). European Commision.

Corrales J., Kristofco L.A., Steele W.B., Yates B.S., Breed Ch.S., Williams E.S. \& Brooks B.W., 2015. Global Assessment of Bisphenol A in the Environment: Review and Analysis of Its Occurrence and Bioaccumulation. Dose-Response: An International Journal, 13(3), 1-29, https://doi.org/10.1177/1559325815598308.

Cunningham V., Buzby M., Hutchinson T., Mastrocco F., Parke N. \& Roden N., 2006. Effects of human pharmaceuticals on Aquatic Life: Next Steps. How do human pharmaceuticals get into the environment, and what are their effects? Environmental Science and Technology, 40, 11, 3456-3462, https://doi.org/10.1021/es063017b.

Daneshvar A., Svanfelt J., Kronberg L. \& Weyhenmeyer G.A., 2010. Winter accumulation of acidic pharmaceuticals in a Swedish River. Environmental Science and Pollution Research, 17, 4, 908-916, https://doi.org/10.1007/s11356009-0261-y.

DWD, 2018. Proposal for a Directive of the European Parliament and of the Council on the quality of water intended for human consumption (recast). Brussels, 1.2.2018, $\operatorname{COM}(2017) 753$ final, 2017/0332 (COD).

$\mathrm{ED} / 01 / 2017$. Inclusion of substances of very high concern in the Candidate List for eventual inclusion in Annex XIV (Decision of the European Chemicals Agency). 4.01.2017.

$\mathrm{ED} / 01 / 2018$. Inclusion of substances of very high concern in the Candidate List for eventual inclusion in Annex XIV (Decision of the European Chemicals Agency). 3.01.2018.

EFSA, 2019. Bisphenol A. https://bisphenol-a-europe.org/newlimits-bpa-food-contact-materials/ [access: 1.12.2019].

EU, 2010. European Union Risk Assessment Report, CAS: 80-05-7 EINECS No: 201-245-8, Environment Addendum of April 2008, 4,4'-ISOPROPYLIDENEDIPHENOL (Bisphenol-A), Part 1 Environment, http://publications.jrc. ec.europa.eu/repository/bitstream/111111111/15063/1/ lbna24588enn.pdf [access: 1.12.2019].

EU, 2013. Directive 2013/39/EU of the European Parliament and of the Council of 12 August 2013 amending Directives 2000/60/EC and 2008/105/EC as regards priority substances in the field of water policy. 
EU, 2015. Commission Implementing Decision 2015/495. Commission Implementing Decision (EU) 2015/495 of 20 March 2015 establishing a watch list of substances for Union-wide monitoring in the field of water policy pursuant to Directive 2008/105/EC of the European Parliament and of the Council (notified under document C(2015) 1756)

Fischer B., Milunov M., Floredo Y., Hofbauer P. \& Joas A., 2014. Identification of relevant emission pathways to the environment and quantification of environmental exposure for Bisphenol A. Federal Environment Agency (Umweltbundesamt), https://www.umweltbundesamt. de/sites/default/files/medien/378/publikationen/texte_ 41_2014_identfifcation_of_relevant_emission_pathways _of_bisphenol_a_0.pdf [access: 1.12.2019].

Fu P.Q. \& Kawamura K., 2010. Ubiquity of bisphenol A in the atmosphere. Environmental Pollution, 158, 10,3138-3143, https://doi.org/10.1016/j.envpol.2010.06.040.

Goodman J.E., Peterson M.K., Hixon M.L., \& Pacheco Shubin S., 2017. Derivation of an oral Maximum Allowable Dose Level for Bisphenol A. Regulatory Toxicology and Pharmacology, 86, 312-318, https://doi.org/10.1016/ j.yrtph.2017.03.024.

GWD, 2006. Directive 2006/118/EC of the European Parliament and of the Council of 12 December 2006 on the protection of groundwater against pollution and deterioration.

Hansen A.B. \& Lassen P., 2008. Screening of phenolic substances in the Nordic environments. Nordic Council of Ministers. Tema Nord. 2008; 530:145.

Kapelewska J., Kotowska U., Karpińska J., Kowalczuk D., Arciszewska A. \& Świrydo A., 2018. Occurrence, removal, mass loading and environmental risk assessment of emerging organic contaminants in leachates, groundwaters and wastewaters. Microchemical Journal, 137, 292-301, https://doi.org/10.1016/j.microc.2017.11.008.

Kmiecik E., Styszko K., Wątor K., Durak J. \& Dwornik M., 2017a. Obecność w wodach podziemnych substancji zaburzających gospodarkę hormonalną człowieka - wyniki badań wstępnych [The occurence of endocrine disrupting compounds in groundwater - preliminary results]. [in:] Transformacja zanieczyszczeń w środowisku: II ogólnopolska konferencja naukowa: Kraków, 14-15 grudnia 2017: materiały konferencyjne, Kraków, 11.

Kmiecik E., Wątor K., Dwornik K. \& Styszko K., 2017b. Preliminary results of ibuprofen residue determination in water from southern Poland. [in:]: IWA 10th micropol \& ecohazars conference: 17-20 September 2017, Vienna, Austria, Vienna, 1.

Kmiecik E., Wątor K., Styszko K. \& Durak J., 2018. The occurrence of bisphenol A in selected bottled water - preliminary results. [in:] Water JPI 2018 Conference: emerging pollutants in freshwater ecosystems: 6-7th of June Helsinki, Finland: abstract book, Helsinki, 17, http:// www.aka.fi/globalassets/30tiedepoliittinen-toiminta/ kv-toiminta/water-jpi/water-jpi-2018-abstract-book.pdf [access: 1.12.2019].

Kozisek F., Pomykacova I., Jeligova H., Cadek V. \& Svobodova V., 2013. Survey of human pharmaceuticals in drinking water in the Czech Republic. Journal of Water and Health, 11(1), 84-97, https://doi.org/10.2166/wh.2013.056.

Krishnan A.V., Stathis P., Permuth S.F., Tokes L. \& Feldman D., 1993. Bisphenol-A: an estrogenic substance is released from polycarbonate flasks during autoclaving. Endocrinology, 32, 6, 2279-2286, https://doi.org/10.1210/ en.132.6.2279.

Kryłów M. \& Rezka P., 2017. Sources of endocrine-disrupting compounds and their migration to the environment. Technical Transactions, 11/2017, 127-135, https://doi.org/ 10.4467/2353737xct.17.197.7426.

Kuczyńska I., 2017. Wyniki pilotażowego badania zawartości substancji czynnych farmaceutyków w wodach podziemnych w próbkach wody pobranych $\mathrm{z}$ krajowej sieci monitoringu wód podziemnych [Results of a pilot study on the assessment of pharmaceuticals in groundwater in samples collected from the national groundwater monitoring network]. Przegląd Geologiczny, 65, 11/1, 1096-1103.

Kümmerer K., 2009. The presence of pharmaceuticals in the environment due to human use - present knowledge and future challenges. Journal of Environmental Management, 90, 8, 2354-2366, https://doi.org/10.1016/ j.jenvman.2009.01.023.

Küster A. \& Adler N, 2014. Pharmaceuticals in the environment: scientific evidence of risks and its regulation. Philosophical Transactions of the Royal Society B, 369(1656), 20130587, https://doi.org/10.1098/rstb.2013.0587.

Lapworth D.J., Baran N., Stuart M.E. \& Ward R.S., 2012. Emerging organic contaminants in groundwater: A review of sources, fate and occurrence. Environmental Pollution, 163, 287-303, https://doi.org/10.1016/j.envpol. 2011.12.034.

Lapworth D.J., Lopez B., Laabs V., Kozel R., Wolter R., Ward R., Vargas Amelin E., Besien T., Claessens J., Delloye F., Ferretti E. \& Grath J., 2019. Developing a groundwater watch list for substances of emerging concern: a European perspective. Environmental Research Letters, 14, 3, 035004, https://doi.org/10.1088\%2F1748-9326\%2Faaf4d7.

Lin Y.Ch., Wei-Po L.W., Tung H. \& Yu-Chen L.A., 2015. Occurrence of pharmaceuticals, hormones, and perfluorinated compounds in groundwater in Taiwan. Environmental Monitoring and Assessment, 187, 256, https:/doi. org/10.1007/s10661-015-4497-3.

Loos R., Locoro G., Comero S., Contini S., Schwesig D., Werres F., Balsaa P., Gans O., Weiss S., Blaha L., Bolchi M. \& Gawlik B.M., 2010. Pan-European survey on the occurrence of selected polar organic persistent pollutants in ground water. Water Research, 44, 14, 4115-4126, https://doi.org/10.1016/j.watres.2010.05.032.

Loos R., 2012. Analytical methods relevant to the European Commission's 2012 proposal on Priority Substances under the Water Framework Directive. JRC Science and Policy Reports, European Commission.

Loos R., 2015. Analytical methods for possible WFD 1st watch list substances. JRC Science and Policy Reports, European Commission.

Lyons R., Van de Bittner K. \& Morgan-Jones S., 2014. Deposition patterns and transport mechanisms for the endocrine disruptor 4-nonylphenol across the Sierra Nevada Mountains, California. Environmental Pollution, 195, 123-132, https://doi.org/10.1016/j.envpol.2014.08.006.

MDH, 2015: Toxicological Summary for: Bisphenol A. Health Based Guidance for Water Health Risk Assessment Unit, Environmental Health Division 651-201-4899, Minnesota Department of Health. 
Nosek K., Styszko K. \& Gołaś J., 2014. Combined method of solid-phase extraction and GC-MS for determination of acidic, neutral, and basic emerging contaminants in wastewater (Poland). International Journal of Environmental Analytical Chemistry, 94, 10, 961-974, https://doi. org/10.1080/03067319.2014.900680.

Okońska M. \& Pietrewicz K., 2018. Identification of mathematical model and parameter estimation of erythromycin migration in two different porous media based on column tests. Geologia Croatica, 71, 2, 47-53, http:// www.geologia-croatica.hr/index.php/GC/article/view/ gc.2018.05

Okońska M., Kaczmarek M. \& Marciniak M., 2019a. The pulse descriptors in sensitivity studies of hybrid sorption column transport models. Journal of Porous $\mathrm{Me}$ dia, 22, 6, 647-662, https://doi.org/10.1615/JPorMedia. 2019028916.

Okońska M., Marciniak M. \& Kaczmarek M., 2019b. The pulse descriptors in sensitivity studies of no-sorption and single-sorption column transport models. Journal of Porous Media, 22, 5, 563-582, https://doi.org/10.1615/ JPorMedia.2019028912.

Okońska M., Marciniak M., Zembrzuska J. \& Kaczmarek M., 2019c. Laboratory investigations of diclofenac migration in saturated porous media - a case study. Geologos, 25, 3, 213-223, https://doi.org/10.2478/logos-2019-0023.

Paxéus N., Bester K. \& El-taliawy H., 2016. Temporal variations and trends in loads of commonly used pharmaceuticals to large wastewater treatment plants in Sweden, a case study (Ryaverket). Water Science and Technology, 73, 12, 3049-3056, https://doi.org/10.2166/wst.2016.179.

Petrie B., Youdan J., Barden R. \& Kasprzyk-Hordern B., 2016. Multi-residue analysis of 90 emerging contaminants in liquid and solid environmental matrices by ultra-high-performance liquid chromatography tandem mass spectrometry. Journal of Chromatography A, 1431, 64-78, https://doi.org/10.1016/j.chroma.2015.12.036.

Postigo C. \& Barceló D., 2015. Synthetic organic compounds and their transformation products in groundwater: Occurrence, fate and mitigation. Science of the Total Environment 503-504, 32-47, https://doi.org/10.1016/j.scitotenv. 2014.06.019.

Pubchem, 2017. Bisphenol A. https://pubchem.ncbi.nlm.nih. gov/compound/6623 [access: 1.12.2019].

Rasheed T., Bilal M., Nabeel F., Adeel M. \& Iqbal H.M.N., 2019. Environmentally-related contaminants of high concern: Potential sources and analytical modalities for detection, quantification, and treatment. Environment International, 122, 52-66, https://doi.org/10.1016/j.envint. 2018.11.038.

Rocha M.J., Cruzeiro C. \& Rocha E., 2013. Development and validation of a GC-MS method for the evaluation of 17 endocrine disruptor compounds, including phytoestrogens and sitosterol, in coastal waters - their spatial and seasonal levels in Porto costal region (Portugal). Journal of Water and Health, 11, 2, 281-296, https://doi. org/10.2166/wh.2013.021.

Rudel R.A., Camann D.E., Spengler J.D., Korn L.R. \& Brody J.G., 2003. Phthalates, alkylphenols, pesticides, polybrominated diphenyl ethers, and other endocrine-disrupting compounds in indoor air and dust.
Environmental Science and Technology, 37, 20, 45434553, https://doi.org/10.1021/es0264596.

Rykowska I. \& Wasiak W., 2006. Properties, Threats, and Methods of Analysis of Bisphenol A and Its Derivatives. Acta Chromatographica, 16, 7-27.

Salgueiro-González N., López de Alda M.J., Muniategui-Lorenzo S., Prada-Rodríguez D. \& Barceló D., 2015. Analysis and occurrence of endocrine-disrupting chemicals in airborne particles. TrAC, Trends in Analytical Chemistry, 66, 45-52, https://doi.org/10.1016/j.trac.2014.11.006.

Sánchez-Brunete C., Miguel E. \& Tadeo J.L., 2009. Determination of tetrabromobisphenol-A, tetrachlorobisphenol-A and bisphenol-A in soil by ultrasonic assisted extraction and gas chromatography-mass spectrometry. Journal of Chromatography A, 1216, 29, 5497-5503, https://doi.org/10.1016/j.chroma.2009.05.065.

Sanderson H., 2011. Presence and risk assessment of pharmaceuticals in surface water and drinking water. Water Science and Technology, 63, 10, 2143-2148, https://doi. org/10.2166/wst.2011.341.

Schaider L.A., Rudel R.A., Ackerman J.M., Dunagan S.C. \& Brody J.G., 2014. Pharmaceuticals, perfluorosurfactants, and other organic wastewater compounds in public drinking water wells in a shallow sand and gravel aquifer. Science of the Total Environment, 468-469, 384-393, https://doi.org/10.1016/j.scitotenv.2013.08.067.

Snyder S.A. \& Benotti M.J., 2010. Endocrine disruptors and pharmaceuticals: implications for water sustainability. Water Science and Technology, 61, 1, 145-154, https://doi. org/10.2166/wst.2010.791.

Styszko K., 2016. Sorption of emerging organic micropollutants onto fine sediments in a water supply dam reservoir, Poland. Journal of Soil and Sediments, 16, 2, 677-686, https://doi.org/10.1007/s11368-015-1239-7.

Vandenberg L.N., Hauser R., Marcus M., Olea N. \& Welshons W.V., 2007. Human exposure to bisphenol A (BPA). Reproductive Toxicology, 24, 2, 139-177, https:/doi.org/ 10.1016/j.reprotox.2007.07.010.

Vogel S.A., 2009. The politics of plastics: the making and unmaking of bisphenol a "safety". American Journal of Public Health, 99, 3, 559-566, https://doi.org/10.2105/ AJPH.2008.159228.

Vorkamp K., Bossi R., Bester K., Bollmann U.E. \& Boutrup S., 2014. New priority substances of the European Water Framework Directive: biocides, pesticides and brominated flame retardants in the aquatic environment of Denmark. Science of the Total Environment, 470-471, 459-468, https://doi.org/10.1016/j.scitotenv.2013.09.096.

Wazir U. \& Mokbel K., 2019. Bisphenol A: A Concise Review of Literature and a Discussion of Health and Regulatory Implications. In vivo, 33, 1421-1423, https://doi. org/10.21873/invivo.11619.

Wątor K., Kmiecik E., Dwornik M. \& Styszko K., 2017. Bisfenol A w wodach - wyniki badań wstępnych [Bisphenol A in waters - results of preliminary studies]. Acta Balneologica, 59, 3, 244-245.

Webb S., Ternes T., Gibert M. \& Olejniczak K., 2013. Indirect human exposure to pharmaceuticals via drinking water. Toxicology Letters, 142, 157-167, https://doi.org/10.1016/ S0378-4274(03)00071-7. 
WFD, 2000. Directive 2000/60/EC of the European Parliament and of the Council of 23 October 2000 establishing a framework for Community action in the field of water policy.

WHO, 2012. Pharmaceuticals in drinking-water. World Health Organization, Geneva.

Wilson N.K., Lyu C., Chuang J.C. \& Morgan M.K., 2001. Levels of persistent organic pollutants in several child day care centers. Journal of Exposure Analysis and Environmental Epidemiology, 11, 449-458, https://doi.org/ 10.1038/sj.jea.7500190.
Witczak S., Kania J. \& Kmiecik E., 2013. Katalog wybranych fizycznych i chemicznych wskaźników zanieczyszczeń wód podziemnych i metod ich oznaczania. Biblioteka Monitoringu Środowiska, Inspekcja Ochrony Środowiska, Warszawa, www.gios.gov.pl/images/dokumenty/ raporty/ebook2_20130422.pdf [access: 1.12.2019].

Yan L., Lv D., Huang X., Shi H. \& Zhang G., 2016. Adsorption characteristics of bisphenol-A on tailored activated carbon in aqueous solutions. Water Science and Technology, 74, 7, 1744-1751, https://doi.org/10.2166/wst.2016.325. 